\section{P269 DESCRIBING ADHERENCE DATA IN A CLINICAL EFFECTIVENESS TRIAL: THE SALFORD LUNG STUDY IN COPD (SLS COPD)}

10.1136/thoraxjnl-2017-210983.468

S Collier: Employment and stock ownership (GSK)

D Browning: Employment and stock ownership (GSK)

JP New: During the SLS COPD study, JPN received research funding towards post via NorthWest EHealth, Salford, UK

JM Gibson: Employing organisation provided IT support for automated data capture collected during SLS COPD

L Stephens: Employment and stock ownership (GSK)

N Diar Bakerly: NDB employing organisation provided IT support to automated data collection method for the SLS COPD trial. NDB received financial support to attend meetings in the form of non-restricting educational grants from GSK, Novartis, AZ, and BI.

J Fletcher: Employment and stock ownership (GSK)

J Crawford: Employment and stock ownership (GSK)

\section{P270 IDENTIFICATION OF RESPONDER GROUPS TO FLUTICASONE FUROATE/VILANTEROL (FF/VI) IN THE SALFORD LUNG STUDY IN COPD (SLS COPD) USING A CLUSTER ANALYSIS MODEL}

10.1136/thoraxjnl-2017-210983.469

A Nicholls: Employment and stock ownership (GSK)

N Diar Bakerly: Employing organisation provided IT support to automated data collection method for the SLS COPD trial. NDB received financial support to attend meeting in the form of non-restricting educational grants from GSK, Novartis, Astra Zeneca and BI

$S$ Collier: Employment and stock ownership (GSK)

H Dickinson: Employment and stock ownership (GSK)

D Leather: Employment and stock ownership (GSK)

I Boucot: Employment and stock ownership (GSK)

\section{P271 EFFECT OF EXTRAFINE SINGLE INHALER TRIPLE THERAPY ON LUNG FUNCTION AND USE OF RESCUE MEDICATION: RESULTS FROM THE TRINITY STUDY}

\subsection{6/thoraxjnl-2017-210983.470}

The research was funded by Chiesi Farmaceutici S.p.A.

M Scuri, I Montagna, C Francisco, G Cohuet, S Vezzoli, A Muraro and S Petruzzelli are employees of Chiesi Farmaceutici S.p.A.

$\mathrm{J}$ Vestbo has received honoraria from AstraZeneca, Boehringer-Ingelheim, Chiesi, GSK and Novartis.

D Singh has received honoraria from Apellis, AstraZeneca, Boehringer Ingelheim, Chiesi, Cipla, Genentech, GlaxoSmithKline, Glenmark, Johnson and Johnson, Menarini, Mundipharma, Novartis, Peptinnovate, Pfizer, Pulmatrix, Skypharma, Teva, Therevance and Verona.

M Corradi has received honoraria from Chiesi.

A Papi reports grants, personal fees, and/or reimbursement of travel expenses from Astrazeneca, Chiesi, Boehringer
Ingelheim, GlaxoSmithKline, Menarini, Merck Sharp \& Dohme, Mundipharma, Novartis, Teva, Sanofi, Zambon.

\section{P272 IMPROVEMENTS IN EXACERBATION RATES WITH SINGLE INHALER TRIPLE THERAPY VERSUS DUAL ICS/ LABA THERAPY IN PATIENTS WITH ADVANCED CHRONIC OBSTRUCTIVE PULMONARY DISEASE (COPD): SUBGROUP ANALYSES OF THE PHASE III FULFIL STUDY}

10.1136/thoraxjnl-2017-210983.471

E Hilton employee of GSK and holds stock options/shares

$\mathrm{N}$ Brearley employee of GSK and holds stock options/ shares

R Birk employee of GSK and holds stock options/shares

C-Q Zhu employee of GSK and holds stock options/shares

GJ Criner received grants from US NIH and the Department of Defense, consulting from AstraZeneca, Boehringer Ingelheim, Holaira, Mereo, Third Pole, PneumRX, Pulmonx, Pearl, Amirall, CSA Medical, Broncus, AVISA, Lungpacer and GlaxoSmithKline; and contracted clinical trials from AstraZeneca, Avisa, Mereo,Boehringer Ingelheim, Broncus, GlaxoSmithKline, Lungpacer,Novartis, Pulmonx, PneumRx/BTG, and Yungjin

M Dransfield received grants from US NIH and the Department of Defense, consulting from AstraZeneca, Boehringer Ingelheim, Boston Scientific, Genentech, and GlaxoSmithKline; and contracted clinical trials from AstraZeneca, Boehringer Ingelheim, Boston Scientific, GlaxoSmithKline, Novartis, Pulmonx, PneumRx/BTG, and Yungjin

D Halpin received personal fees from GSK; personal fees and non-financial support from AstraZeneca; personal fees and non-financial support from Boehringer Ingelheim; personal fees and non-financial support from Novartis; personal fees from Pfizer; personal fees from Chiesi

DA Lomas received grants, honoraria, and consultancy fees from GSK and chaired the GSK Respiratory Therapy Area Board from 2012-2015

DA Lipson employee of GSK and holds stock options/ shares

\section{P273 ASSOCIATION OF INCIDENT PNEUMONIA AND EXACERBATIONS WITH EXTRAFINE TRIPLE THERAPY IN ONE SINGLE INHALER IN COPD PATIENTS: A POST-HOC ANALYSIS FROM TRILOGY AND TRINITY STUDIES}

10.1136/thoraxjnl-2017-210983.472

The research was funded by Chiesi Farmaceutici S.p.A.

M Scuri, M Spinola, I Montagna, C Francisco, G Cohuet, S Vezzoli, A Muraro and S Petruzzelli are employees of Chiesi Farmaceutici S.p.A.

$\mathrm{J}$ Vestbo has received honoraria from AstraZeneca, Boehringer-Ingelheim, Chiesi, GSK and Novartis.

D Singh has received honoraria from Apellis, AstraZeneca, Boehringer Ingelheim, Chiesi, Cipla, Genentech, GlaxoSmithKline, Glenmark, Johnson and Johnson, Menarini, Mundipharma, Novartis, Peptinnovate, Pfizer, Pulmatrix, Skypharma, Teva, Therevance and Verona.

M Corradi has received honoraria from Chiesi. 